\title{
SISTEM PENUNJANG KEPUTUSAN PEMILIHAN SEKOLAH MENENGAH KEJURUAN TEKNIK KOMPUTER DAN JARINGAN YANG TERFAVORIT DENGAN MENGGUNAKAN MULTI-CRITERIA DECISION MAKING
}

\author{
Faisal ${ }^{1}$, Silvester Dian Handy Permana ${ }^{2}$ \\ ${ }^{1,2}$ Fakultas Telematika Universitas Trilogi \\ Email:, ${ }^{1}$ faisalpiliang@universitas-trilogi.ac.id; ${ }^{2}$ handy@universitas-trilogi.ac.id
}

(Naskah masuk: 29 Januari 2015, diterima untuk diterbitkan: 17 Februari 2015)

\begin{abstract}
Abstrak
Sistem pendukung keputusan (SPK) adalah sebuah sistem yang dapat membantu seseorang dalam mengambil keputusan dari berbagai jenis pilihan yang dilakukan secara akurat dan sesuai dengan sasaran yang diinginkan. Banyak permasalahan yang dapat diselesaikan dengan menggunakan sistem pendukung keputusan. Dalam makalah ini sistem pendukung keputusan digunakan untuk membantu para lulusan siswa-siswi Sekolah Menengah Pertama (SMP) dalam menentukan pilihan masuk atau melanjutkan sekolahnya ke sebuah Sekolah Menengah Kejuruan Teknik Komputer Dan Jaringan (SMK TKJ) yang favorit dari beberapa pilihan sekolah yang ada yang ingin mereka pilih sebagai lanjutan tahapan pendidikan berikutnya. Metode yang digunakan dalam penelitian ini yaitu menggunakan metode Multi-Criteria Decision Making (MCDM) dan Analytical Hierarchy Process (AHP), karena metode yang paling banyak digunakan dalam memecahkan permasalahan yang bersifat multi kriteria, seperti memecahkan masalah sistem pendukung keputusan dalam menentukan pemilihan masuk ke Sekolah Menengah Kejuruan Teknik Komputer Dan Jaringan (SMK TKJ) yang favorit. Hasil akhir dari penelitian ini yaitu nilai bobot $44,8 \%$ dari jawaban reponden memilih SMK TI 2, nilai bobot 29,3\% dari jawaban reponden memilih SMK TI 1 dan nilai bobot 25,9\% dari jawaban reponden memilih SMK TI 3 sebagai pilihan sekolah mereka.
\end{abstract}

Kata kunci: Sistem pendukung keputusan, Pemilihan SMK TKJ, Multi-Criteria Decision System, Analytical Hierarchy Process

\begin{abstract}
Decision support system (DSS) is systems that can help a person to make decisions on the various types of options are done accurately and in accordance with the desired goals. Many problems can be solved by using decision support systems. In this research the decision support system is used to help the Junior High School (SMP) graduate students in determining the choice to enter or continue their education to a favorite Vocational High School of Computer Engineering and Networks (SMK TKJ) that anyone wants they select as an advanced stage subsequent education. The method used in this research is using Multi-Criteria Decision Making (MCDM) and Analytical Hierarchy Process (AHP), because it is the most widely used method in solving the problems that are multi-criteria, such as decision support systems to solve problems in determining the election into the favorite Vocational High School of Computer Engineering and Networks (SMK TKJ). The end result of this research is $44.8 \%$ weighted value of the respondents answers is chose the SMK TI 2, 29.3\% weight value of the respondents answers is chose the SMK TI 1 and 25,9\% weight value of the respondents answers is chose the SMK TI 3 as their favorite school.
\end{abstract}

Keywords: Decision support system, Election SMK TKJ, Multi-Criteria Decision System, Analytical Hierarchy Process

\section{PENDAHULUAN}

Perkembangan Information Communication Technology (ICT) semakin hari semakin meningkat dengan cepat, baik perkembangan dibidang industri maupun perkembangan di lingkungan pendidikan. Banyak fasilitas-fasilitas yang bisa kita dapatkan dengan mudah karena adanya kemajuan teknologi Information Communication Technology (ICT).
Dunia kerja saat ini juga menuntut seluruh karyawannya untuk bisa mengikuti perkembangan Information Communication Technology (ICT) yang tersedia saat ini. Sesuai dengan uraian diatas Information Communication Technology (ICT) juga sangat diperlukan didalam bidang pendidikan, agar dapat membekali dan juga mempersiapkan anak didiknya dengan kemajuan Information Communication Technology (ICT). 
Menentukan pilihan sekolah yang tepat adalah salah satu hal yang sangat penting dalam hidup. Karena pilihan untuk sekolah saat ini, akan mempengaruhi pendidikan dan kehidupan masa depan kelak. Bila pilihannya tepat, maka apa yang didapat di sekolah akan menjadi bekal yang cukup dalam mengenyam pendidikan yang lebih tinggi lagi. Dan kelak, juga akan mempengaruhi bidang pekerjaan yang akan ditekuni. Salah satu permasalahan yang dihadapi oleh para siswa dan juga dialami oleh orangtuanya adalah terdapat banyaknya pilihan sekolah yang dapat membingungkan calon siswa dalam memilih sekolah sehingga calon siswa mengalami kesulitan untuk mendapatkan data dan informasi secara lengkap.

Menyadari betapa pentingnya dalam menentukan pilihan sekolah yang tepat, maka perlu dibuatkan sistem pendukung keputusan (SPK) yang dapat membantu para siswa-siswi lulusan Sekolah Menengah Pertama (SMP) dan atau Madrasah Tsanawiyah (MTs) dalam menentukan pilihan masuk atau melanjutkan sekolahnya ke sebuah Sekolah Menengah Kejuruan Teknik Komputer Dan Jaringan (SMK TKJ) yang favorit dengan menggunakan perangkat lunak Expert Choice $2000^{\mathrm{TM}}$ untuk teknis analisa Analytical Hierarchy Process (AHP).

Berdasarkan latar belakang diatas, serta untuk menentukan arah dari penulisan ini, dengan demikian perumusan permasalahan yang ada adalah "Bagaimana cara untuk membantu siswa dalam menentukan pilihan masuk atau melanjutkan sekolahnya ke sebuah Sekolah Menengah Kejuruan (SMK) berprogram studi Teknologi Informasi (TI) yang favorit yang sesuai dengan bakat dan akademik masing-masing siswa sehingga dapat meningkatkan mutu dan pelayanan terhadap siswa?".

Tujuan penelitian ini adalah menghasilkan sebuah Sistem Pendukung Keputusan (SPK) untuk mempermudah pengambilan keputusan penentuan melanjutkan ke sebuah Sekolah Menengah Kejuruan (SMK) berprogram studi Teknologi Informasi (TI) yang favorit, dengan menggunakan perangkat lunak Expert Choice $2000^{\mathrm{TM}}$ untuk teknis analisa Analytical Hierarchy Process (AHP). Sehingga dapat membantu para siswa-siswi lulusan SMP atau MTs tersebut umumnya dan khususnya bagi guru, dan orang tua siswa di sekolah tersebut dalam menentukan sekolah yang tepat untuk yang sesuai dengan minat serta kemampuan yang dimiliki.

\section{TINJAUAN PUSTAKA}

\subsection{Konsep Sistem}

Sistem merupakan suatu jaringan prosedurprosedur yang saling berhubungan dan atau saling berkumpul untuk melakukan suatu interaksi berupa suatu kegiatan atau suatu proses kerja dalam menyelesaikan suatu tujuan dari sistem tersebut. Prosedur merupakan suatu urutan dari tindakan atau aksi yang disusun untuk menjamin adanya perlakuan yang seragam terhadap kejadian yang berlangsung berulang-ulang. Maksud dari adanya sistem adalah untuk mencapai tujuan pokok dari sistem tersebut. Tujuan pokok ini akan terlaksana apabila terdapat elemen-elemen dan prosedur-prosedur di dalam sistem yang saling berhubungan membentuk satu kesatuan (Jogiyanto, 2008).

\subsection{Sistem Pendukung Keputusan (SPK)}

Konsep Sistem Pendukung Keputusan atau Decision Support System pertama kali diungkapkan pada awal tahun 1970-an oleh Michael S. Scott Morton dengan istilah Management Decision System. Definisi dari Sistem Pendukung Keputusan adalah suatu sistem berbasis komputer yang ditujukan untuk membantu pengambilan keputusan dalam memanfaatkan data dan model tertentu untuk memecahkan berbagai persoalan yang tidak terstruktur (Daihani, 2001).

Sistem Pendukung Keputusan mengacu pada suatu sistem yang memanfaatkan dukungan komputer dalam proses pengambilan keputusan. Hal ini dikemukakan oleh beberapa ahli, diantaranya Little Man dan Watson memberi definisi bahwa Sistem Pendukung Keputusan merupakan suatu sistem yang interaktif, yang membantu pengambil keputusan melalui penggunaan data dan modelmodel keputusan untuk memecahkan masalahmasalah yang sifatnya semi terstruktur dan tidak terstruktur (Suryadi, 2001).

Dari berbagai definisi diatas dapat dikatakan bahwa Sistem Pendukung Keputusan adalah suatu sistem informasi spesifik yang ditujukan untuk membantu manajemen dalam mengambil keputusan yang berkaitan dengan persoalan yang bersifat semi terstruktur (hukum sebab-akibat dari adanya suatu variabel belum pasti/bukan suatu rutinitas). Sistem ini mampu menghasilkan berbagai alternatif yang secara interaktif dapat digunakan oleh pemakai (Davis, 1999).

Sistem pendukung keputusan adalah sistem berbasis komputer interaktif yang membantu pengguna dalam penilaian dan pemilihan. Sistem tidak hanya menyediakan penyimpanan dan pengambilan data tapi juga meningkatkan akses informasi tradisional dengan dukungan untuk pembuatan model pengambilan keputusan dan penalaran berbasis model (Roger \& Marek, 2007). 


\subsection{Multiple Criteria Decision Making (MCDM)}

Multiple Criteria Decision Making (MCDM) merupakan salah satu metode yang paling banyak digunakan dalam area pengambilan keputusan. Tujuan dari MCDM adalah memilih alternatif terbaik dari beberapa alternatif eksklusif yang saling menguntungkan atas dasar performansi umum dalam bermacam kriteria (atau atribut) yang ditentukan oleh pengambil keputusan (Chen, 2005:10 dalam Sri Andayani, 2012).

\subsection{Metode Analytical Hierarchy Process (AHP)}

Mengambil keputusan adalah suatu proses yang dilaksanakan orang berdasarkan pengetahuan dan informasi yang ada dengan harapan bahwa akan terjadi. Keputusan dapat diambil dari alternatifalternatif keputusan yang ada. Alternatif keputusan itu dapat dilakukan dengan adanya informasi yang diolah dan disajikan dengan dukungan sistem penunjang keputusan. Adapun informasi terbentuk dari adanya data yang terdiri dari bilangan dan terms yang disusun, diolah, dan disajikan dengan dukungan sistem informasi manajemen. Kemudian keputusan yang diambil ditindaklanjuti dengan aksi yang dalam pelaksanaanya perlu mengacu pada standar prosedur operasi, dan akan membentuk kembali data, begitu seterusnya yang terjadi pada siklus data, informasi, keputusan, dan aksi.

Pengambilan keputusan dapat dilakukan dengan dua kerangka kerja, meliputi:

1. Pengambilan keputusan tanpa percobaan

2. Pengambilan keputusan yang berdasarkan suatu percobaan.

Pengambilan keputusan tanpa berdasarkan eksperimen, dilakukan dengan cara menyusun secara sistematis cara kerja umum sebelum mencari solusi bagi masalah yang diharapkan. Teori ini dikembangkan sejalan dengan pendekatan statistik di mana secara sederhana, keputusan yang dihasilkan diupayakan mempunyai pengaruh kesalahan seminimum mungkin.

Dalam kehidupan sehari-hari pengambilan keputusan sering menggunakan intuisi, walaupun metode ini banyak sekali kekurangan sehingga dikembangkan sistematika baru yang disebut dengan analisis keputusan, yaitu kecerdasan, persepsi, dan falsafah. Setelah menggunakan kecerdasan, persepsi, dan falsafah untuk membuat model, menentukan nilai kemungkinan, menetapkan nilai pada hasil yang diharapkan dan menjajaki preferensi terhadap waktu dan preferensi terhadap resiko, maka untuk sampai pada suatu keputusan diperlukan logika.

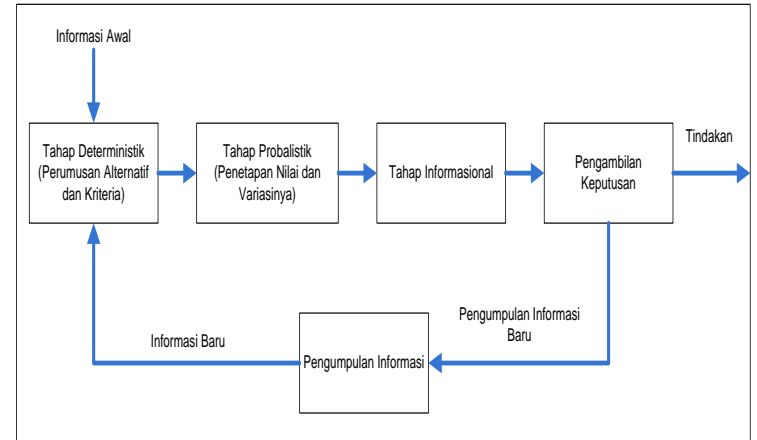

Gambar 1. Bagan Siklus Analisis Keputusan Rasional (MARIMIN, 2004)

Dari gambar 1 menjelaskan informasi awal yang dikumpulkan, dilakukan pendefinisian dan penghubungan variabel-variabel yang mempengaruhi keputusan pada tahap deterministik. Setelah itu dilakukan penetapan nilai untuk mengukur tingkat kepentingan variabel-variabel tersebut tanpa memperhatikan unsur-unsur ketidakpastian. Pada tahap probabilistik, dilakukan penetapan nilai ketidakpastian secara kuantitatif yang meliputi variabel-variabel yang sangat berpengaruh. Setelah didapatkan nilai-nilai variabel, selanjutnya dilakukan peninjauan terhadap nilai-nilai tersebut pada tahap informasional untuk menentukan nilai ekonomisnya pada variabel-variabel yang cukup berpengaruh, sehingga di dapatkan suatu keputusan. Keputusan yang dihasilkan dari tahap informasional dapat langsung ditindaklajuti beberapa tindakan, atau dapat dikaji ulang dengan mengumpulkan informasi tambahan dengan tujuan untuk mengurangi kadar ketidakpastian. Dan jika hal ini terjadi, maka akan kembali mengikuti ketiga tahap tersebut, begitu seterusnya.

Salah satu model yang dapat digunakan sebagai proses pengambilan keputusan adalah dengan menggunakan Proses Hierarki Analitik atau yang dikenal dengan istilah Analytical Hierarchy Process (AHP). Proses Hierarki Analitik (AHP) dikembangkan oleh Dr. Thomas L. Saaty dari Wharton School of Business pada tahun 1970-an untuk mengorganisasikan informasi dan judgement dalam memilih alternatif yang paling disukai (Saaty, 1983) (MARIMIN, 2004). Dengan menggunakan AHP, suatu persoalan yang akan dipecahkan dalam suatu kerangka berpikir yang terorganisir, sehingga memungkinkan dapat diekspresikan untuk mengambil keputusan yang efektif atas persoalan tersebut. Persoalan yang kompleks dapat disederhanakan dan dipercepat proses pengambilan keputusannya.

Prinsip kerja AHP adalah menyederhanakan suatu persoalan kompleks yang tidak terstruktur, stratejik, dan dinamik menjadi bagian-bagiannya, serta menata dalam suatu hierarki. Kemudian tingkat kepentingan setiap variabel diberi nilai numerik 
secara subjektif tentang arti penting variabel tersebut secara relatif dibandingkan dengan variabel lain. Dari berbagai pertimbangan tersebut kemudian dilakukan sintesa untuk menetapkan variabel yang memiliki prioritas tertinggi dan peranan untuk mempengaruhi hasil pada sistem tersebut.

Secara grafis, persoalan keputusan AHP dapat dikonstruksikan sebagai diagram bertingkat, yang dimulai dengan goal/sasaran, lalu kriteria level pertama, sub kriteria, dan akhirnya alternatif. AHP memungkinkan pengguna untuk memberikan nilai bobot relatif dari suatu kriteria majemuk (atau alternatif majemuk terhadap suatu kriteria) secara intuitif, yaitu dengan melakukan perbandingan berpasangan (pairwise comparisons). Dr. Thomas L. Saaty, pembuat AHP, kemudian menentukan cara yang konsisten untuk mengubah perbandingan berpasangan/pairwise, menjadi suatu himpunan bilangan yang merepresentasikan prioritas relatif dari setiap kriteria dan alternatif.

AHP memiliki banyak keunggulan dalam menjelaskan proses pengambilan keputusan, karena dapat digambarkan secara grafis, sehingga dapat dipahami oleh semua pihak yang terlibat dalam pengambilan keputusan. Dengan AHP, proses keputusan kompleks dapat diuraikan menjadi keputusan-keputusan lebih kecil yang dapat ditangani lebih mudah. Selain itu, AHP juga menguji konsistensi penilaian, bila terjadi penyimpangan yang terlalu jauh dari nilai konsistensi sempurna maka hal ini menunjukkan bahwa penilaian perlu diperbaiki, atau hierarki harus distruktur ulang.

Beberapa keuntungan yang diperoleh bila memecahkan persoalan pengambilan keputusan dengan menggunakan AHP dapat terlihat dalam table 1 berikut:

TABEL 1. Keuntungan Menggunakan AHP (MARIMIN, 2004)

\begin{tabular}{|c|l|}
\hline KEUNTUNGAN & KETERANGAN \\
\hline Kesatuan & $\begin{array}{l}\text { AHP memberikan satu model tunggal } \\
\text { yang mudah dimengerti, luwes untuk } \\
\text { aneka ragam persoalan tidak terstruktur }\end{array}$ \\
\hline Kompleksitas & $\begin{array}{l}\text { AHP memadukan ancangan deduktif dan } \\
\text { ancangan berdasarkan sistem dalam } \\
\text { memecahkan persoalan kompleks }\end{array}$ \\
\hline $\begin{array}{c}\text { Saling } \\
\text { Ketergantungan }\end{array}$ & $\begin{array}{l}\text { AHP dapat menangani saling } \\
\text { ketergantungan elemen-elemen dalam } \\
\text { suatu sistem dan tidak memaksakan } \\
\text { pemikiran linear }\end{array}$ \\
\hline Penyusunan & $\begin{array}{l}\text { AHP mencerminkan kecendrungan alami } \\
\text { pikiran untuk memilah-milah elemen- } \\
\text { elemen suatu sistem dalam berbagai } \\
\text { tingkat berlainan dan mengelompokkan } \\
\text { unsur yang serupa dalam setiap tingkat }\end{array}$ \\
\hline Pengukuran & $\begin{array}{l}\text { AHP memberi suatu skala untuk } \\
\text { mengukur hal-hal dan terwujud suatu } \\
\text { metode untuk menetapkan prioritas }\end{array}$ \\
\hline Konsistensi & $\begin{array}{l}\text { AHP melacak konsistensi logis dari } \\
\text { pertimbangan-pertimbangan } \\
\text { digunakan untuk menetapkan berbagai }\end{array}$ \\
\hline
\end{tabular}

\begin{tabular}{|c|c|}
\hline & prioritas \\
\hline Sintesis & $\begin{array}{l}\text { AHP menuntun ke suatu taksiran } \\
\text { menyeluruh tentang kebaikan setiap } \\
\text { alternatif }\end{array}$ \\
\hline Tawar Menawar & $\begin{array}{l}\text { AHP mempertimbangkan prioritas- } \\
\text { prioritas relatif dari berbagai faktor } \\
\text { sistem dan memungkinkan organisasi } \\
\text { memilih alternatif terbaik berdasarkan } \\
\text { tujuan-tujuan mereka }\end{array}$ \\
\hline $\begin{array}{l}\text { Penilaian dan } \\
\text { Konsesus }\end{array}$ & $\begin{array}{l}\text { AHP tidak memaksakan konsensus tetapi } \\
\text { mensintesiskan suatu hasil yang } \\
\text { representatif dari berbagai penilaian yang } \\
\text { berbeda }\end{array}$ \\
\hline Pengulangan Proses & $\begin{array}{l}\text { AHP memungkinkan organisasi } \\
\text { memperhalus defenisi mereka pada suatu } \\
\text { persoalan dan memperbaiki } \\
\text { pertimbangan dan pengertian mereka } \\
\text { melalui pengulangan }\end{array}$ \\
\hline
\end{tabular}
berikut

Adapun prinsip kerja AHP adalah sebagai

\section{Penyusunan Hierarki}

Persoalan yang akan diselesaikan diuraikan menjadi unsur-unsurnya, yaitu kriteria dan alternatif, kemudian disusun menjadi struktur hirarki.

\section{Penilaian Kriteria dan Alternatif}

Kriteria dan alternatif dinilai melalui perbandingan berpasangan. Menurut Saaty (1983), untuk berbagai persoalan, skala 1 sampai 9 adalah skala terbaik dalam mengekspresikan pendapat. Nilai dan definisi pendapat kualitatif dari skala perbandingan Saaty dapat dilihat pada table 2 berikut :

TABEL 2. Skala Perbandingan Saaty (MARIMIN, 2004)

\begin{tabular}{|l|l|}
\hline NILAI & KETERANGAN \\
\hline 1 & Kriteria/Alternatif A sama penting dengan kriteria/alternatif B \\
\hline 3 & A sedikit lebih penting dari B \\
\hline 5 & A jelas lebih penting dari B \\
\hline 7 & A sangat jelas lebih penting dari B \\
\hline 9 & A mutlak lebih penting dari B \\
\hline $2,4,6,8$ & Apabila ragu-ragu antara dua nilai yang berdekatan \\
\hline
\end{tabular}

Nilai perbandingan A dengan B adalah 1 (satu) dibagi dengan nilai perbandingan $\mathrm{B}$ dengan $\mathrm{A}$.

3. Penentuan Prioritas

Untuk setiap kriteria dan alternatif, perlu dilakukan perbandingan berpasangan (pairwise comparisons). Nilai-nilai perbandingan relatif kemudian diolah untuk menentukan peringkat relatif dari seluruh alternatif.

Baik kriteria kualitatif maupun kriteria kuantitatif dapat dibandingkan sesuai dengan judgement yang telah ditentukan untuk menghasilkan bobot dan prioritas. Bobot atau prioritas dihitung dengan manipulasi matrik atau melalui penyelesaian persamaan matematik.

\section{Konsistensi Logis}


Semua elemen dikelompokkan secara logis dan diperingkatkan secara konsisten sesuai dengan suatu kriteria yang logis.

Perhitungan indeks konsistensi (CI), pengukuran ini dimaksudkan untuk mengetahui konsistensi jawaban yang akan berpengaruh pada kesahihan hasil. Rumusnya adalah sebagai berikut:

$$
C I=\frac{\lambda_{\max }-n}{n-1}
$$

Untuk mengetahui apakah CI dengan besaran tertentu cukup baik atau tidak, perlu diketahui rasio yang dianggap baik, yaitu apabila:

$$
\mathrm{CR} \leq 0,1
$$

Rumus CR (Consistency Ratio) adalah:

$$
C R=\frac{C I}{R I}
$$

CR merupakan parameter yang digunakan untuk memeriksa apakah perbandingan berpasangan telah dilakukan dengan konsekuen atau tidak. Nilai RI merupakan nilai random indeks yang dikeluarkan oleh Oarkridge Laboratory seperti yang ditampilkan pada tabel 3 berikut:

\begin{tabular}{|c|c|c|c|c|c|c|c|}
\hline $\mathrm{N}$ & 1 & 2 & 3 & 4 & 5 & 6 & 7 \\
\hline RI & 0.00 & 0.00 & 0.58 & 0.90 & 1.12 & 1.24 & 1.32 \\
\hline $\mathrm{N}$ & 8 & 9 & 10 & 11 & 12 & 13 & \\
\hline RI & 1.41 & 1.45 & 1.49 & 1.51 & 1.48 & 1.56 & \\
\hline
\end{tabular}

TABEL 3. Skala Nilai Random Indeks Oarkridge Laboratory (MARIMIN, 2004)

\subsection{Penelitian Terkait}

* Kajian penelitian: Strategi IT Rencana Penanggulangan Bencana (Disaster Recovery Planning/DRP) pada Core UICo System dengan Pendekatan Analytical Hierarchy Process studi kasus UNOCAL Indonesia (Faisal, 2010), dengan tujuan untuk mengetahui efektivitas uji coba Disaster Recovery Planning (DRP) sehingga dapat meminimalisasi kerugian bisnis yang akan ditimbulkan akibat dari kegagalan atau tidak berfungsinya suatu sistem aplikasi. Selain itu penelitian ini juga memberikan rekomendasi pengambil keputusan yang telah dibobotkan berdasarkan tingkat kepentingan perusahaan terhadap penerapan IT DRP pada core UICo system.

* Kajian penelitian: Penerapan metode AHP dalam Pemilihan Komputer dengan menggunakan Expert Choice (Faisal, 2014), dengan tujuan untuk memberikan solusi pada proses pengambilan keputusan yang dapat membantu pihak-pihak tertentu dalam mengambil keputusan yang terbaik dalam pemilihan komputer untuk mencapai hasil yang maksimal. Dengan dilakukannya penelitian ini maka Strategi Pemilihan Komputer dengan menggunakan pendekatan AHP dan menggunakan software Expert Choice $2000^{\mathrm{TM}}$ dapat diterapkan dan hasil akhirnya adalah pemilihan Desktop sebagai prioritas utama dari alternatif strategis yang diambil.

Kajian penelitian: Sistem penunjang keputusan pemilihan perangkat lunak pengolah citra dengan metode Multi-Criteria Decision Making (MCDM) dan Analytical Hierarchy Process (AHP) (Faisal, 2015), dengan tujuan untuk mendukung pemilihan perangkat lunak pengolah citra berdasarkan kriteria dan subkriteria yang telah ditentukan dengan hasil Dreamweaver sebagai prioritas utama disusul Frontpage sebagai prioritas kedua dan Photoshop sebagai prioritas ketiga.

* Kajian penelitian: Sistem penunjang keputusan pemilihan perangkat pemrosesan data menggunakan metode Analytical Hierarchy Process (AHP) dan Multi-Criteria decision Making (MCDM) (Faisal, 2015), dengan tujuan untuk melakukan strategi penentuan pemilihan perangkat pemrosesan data dengan hasil Desktop merupakan prioritas utama dari alternatif strategis yang diambil sebagai penerapan pemilihan perangkat pemrosesan data yang dibuktikan melalui pengolahan data responden ahli disusul urutan prioritas berikutnya Notebook dan Tablet.

* Kajian penelitian: Aplikasi Sistem Pengambilan Keputusan Pemilihan Sekolah (Dedi Trisnawarman dan Margaret Livereja, 2006), dengan tujuan membangun suatu program aplikasi sistem pendukung keputusan pemilihan sekolah berbasis web. Aplikasi diharapkan dapat digunakan untuk mendapatkan informasi dan pengambilan keputusan pemilihan sekolah secara efektif dengan AHP.

* Kajian penelitian: Rancang Bangun Sistem Pengambilan Keputusan Pemilihan SMA Swasta Favorit Degan Metode AHP Berbasis WEB (Parmadiharto, 2007), dengan tujuan memberikan kemudahan pada masyarakat untuk memilih SMA yang sesuai kriteria dengan menerapkan metode AHP, membandingkan antara SMA yang satu dengan yang lain. Sehingga diharapkan sekolah-sekolah tersebut 
akan bersaing positif untuk meningkatkan kualitas terbaiknya.

* Kajian penelitian: Kajian Business Continuity Plan Berdasarkan Kuantifikasi Nilai Ekonomis Sistem Aplikasi Pada Industri Penerbangan: Studi Kasus Pada PT. Garuda Indonesia (EDDY, 2006), dengan tujuan untuk menganalisa pendekatan dalam mengkuantifikasi nilai ekonomis yang timbul akibat kegagalan atau tidak berfungsinya suatu sistem aplikasi TI sebagai dasar dalam melakukan evaluasi dan pengukuran investasi TI yang diharapkan dapat digunakan sebagai bagian dari implementasi BCP. Penelitian tersebut telah mengkuantifikasi nilai manfaat tangible maupun intangible dari sistem aplikasi untuk mengetahui kerugian bisnis dan potensi biaya yang akan timbul bila sistem tidak berfungsi serta biaya untuk mengimplementasikan alternatif-alternatif pendekatan BCP.

* Kajian penelitian: Sistem Pengambilan Keputusan Memilih Perguruan Tinggi Swasta Jurusan Komputer Menggunakan metode AHP (Todhi Pristianto, 2010), dengan tujuan menghasilkan sebuah sistem pendukung keputusan memilih perguruan tinggi swasta jurusan komputer dengan metode AHP, yang diharapkan dapat memberikan informasi perguruan tinggi swasta dan dapat menyelesaikan permasalahan dalam pemilihan perguruan tinggi swasta jurusan komputer di Yogyakarta.

* Kajian penelitian: Aplikasi AHP Sebagai Model Sistem Pengambilan Keputusan Pemilihan Tempat Kuliah di Bangka Belitung (Fitriyani, 2012), dengan tujuan agar para calon mahasiswa atau mahasiswi yang sudah duduk di bangku SMA atau SMK, setidaknya tahu kriteria-kriteria dan alternatif-alternatif apa yang harus dipertimbangkan dalam memilih tempat kuliahnya khususnya di Bangka Belitung.

* Kajian penelitian: Sistem Pengambilan Keputusan Penjurusan SMA Mengunakan Metode AHP (Fitriyani, 2012), dengan tujuan membantu siswa dalam memilih jurusan sesuai dengan bakat dan akademik masing-masing siswa, dengan menggunakan metode AHP sebagai model analisis uji komparasi dan software Expert Choice $2000^{\mathrm{TM}}$ untuk uji komparasi perbandingan berpasangan.

* Kajian penelitian: Sistem Pengambilan Keputusan Penjurusan Dengan Menggunakan Metode AHP Pada SMAN 1 Ngaglik (Riki Khairul, 2012), dengan tujuan agar dapat mempermudah para guru dalam menentukan jurusan apa yang tepat untuk siswanya dilihat dari nilai rata-rata mata pelajaran, nilai test psikotest, minat siswa dan orang tua. Sistem Pengambilan Keputusan ini dapat membantu siswa dalam proses penentuan jurusan yang tepat.

\section{METODE}

Analisa Penelitian diawali dengan pengamatan para siswa-siswi lulusan Sekolah Menengah Pertama (SMP) dan atau Madrasah Tsanawiyah (MTs) dalam menentukan pilihan masuk atau melanjutkan sekolahnya. Penelitian ini menggunakan metode deskriptif analitik dengan menyajikan rangkuman wawancara dan hasil survey yang berupa kuesioner. Selanjutnya dilakukan pencarian data sekunder yang ada di lapangan melalui berbagai media, seperti: internet, buku literatur dan jurnal serta artikel-artikel sehingga didapatkan informasi yang akurat mengenai penentuan pemilihan sekolah.

Berdasarkan hasil wawancara dengan pakar mengenai data, selanjutnya diolah dengan menggunakan pendekatan proses hierarki analitis (AHP) untuk menentukan pilihan masuk atau melanjutkan sekolah. Keputusan yang diperoleh harus segera ditindaklanjuti berupa tindakan atau dapat pula dikaji ulang keputusan tersebut bila ternyata diperoleh informasi baru yang dapat mempengaruhi hasil untuk mengurangi ketidakpastian, maka akan diperoleh keputusan yang baru.

Data sekolah yang digunakan dalam penelitian ini dibatasi hanya data SMP dan MTs diwilayah DKI Jakarta, dan dapat dikembangkan untuk wilayah lain. Kerangka konsep dapat dilihat pada gambar 2 berikut ini:

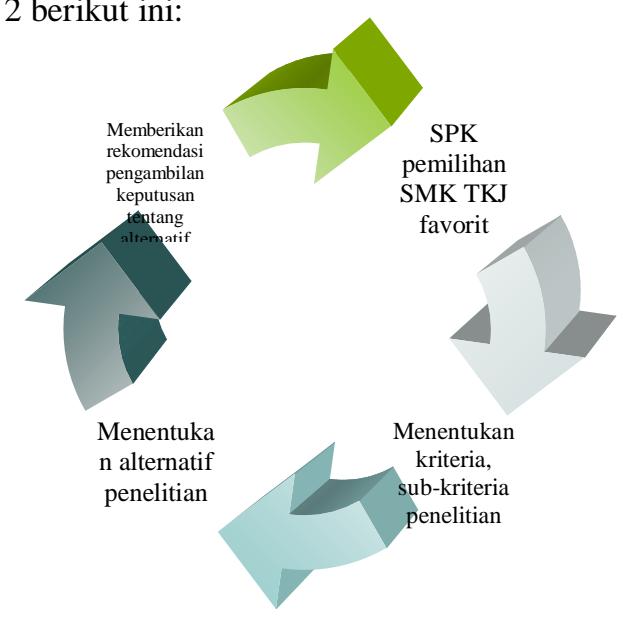

Gambar 2. Kerangka Konsep Pemikiran

Dalam menentukan prioritas langkah-langkah Sistem Penunjang Keputusan pemilihan SMK TKJ favorit, diusulkan sebanyak empat jenis kriteria, tiga 
belas jenis sub-kriteria dan empat jenis alternatif strategis yang mendukung dapat terlihat pada tabel 4 dibawah ini:

TABEL 4. Kriteria, Sub-Kriteria dan alternatif pemilihan SMK TKJ

\begin{tabular}{|c|c|c|c|}
\hline Sasaran & Kriteria & Sub-Kriteria & Alternatif \\
\hline \multirow{13}{*}{$\begin{array}{c}\text { Pemilihan } \\
\text { SMK TI } \\
\text { favorit }\end{array}$} & \multirow{4}{*}{ Fasilitas } & $\begin{array}{l}\text { Gedung } \\
\text { memadai }\end{array}$ & \multirow{6}{*}{ SMK TI 1} \\
\hline & & $\begin{array}{l}\text { Ketersediaan } \\
\text { laboratorium }\end{array}$ & \\
\hline & & $\begin{array}{c}\text { Ketersediaan } \\
\text { Hardware }\end{array}$ & \\
\hline & & $\begin{array}{c}\text { Ketersediaan } \\
\text { Software }\end{array}$ & \\
\hline & \multirow{3}{*}{ Biaya } & $\begin{array}{c}\text { Biaya uang } \\
\text { pangkal }\end{array}$ & \\
\hline & & $\begin{array}{c}\text { Biaya uang } \\
\text { pembangunan }\end{array}$ & \\
\hline & & $\begin{array}{l}\text { Biaya uang } \\
\text { SPP }\end{array}$ & \multirow[t]{4}{*}{ SMK TI 2} \\
\hline & \multirow{3}{*}{ Kwalitas } & $\begin{array}{c}\text { Staff } \\
\text { Pengajar } \\
\text { linear }\end{array}$ & \\
\hline & & Kurikulum IT & \\
\hline & & $\begin{array}{c}\text { Sarana buku } \\
\text { perpustakaan } \\
\text { IT }\end{array}$ & \\
\hline & \multirow{3}{*}{ SDM siswa } & $\begin{array}{c}\text { Lulus ujian } \\
\text { nasional } \\
100 \%\end{array}$ & \multirow{3}{*}{ SMK TI 3} \\
\hline & & $\begin{array}{l}\text { Penyerapan } \\
\text { dunia usaha }\end{array}$ & \\
\hline & & $\begin{array}{l}\text { Masuk ke } \\
\text { PTN }\end{array}$ & \\
\hline
\end{tabular}

Penyelesaian metode pengambilan keputusan dengan AHP dapat menggunakan perangkat lunak Expert Choice $2000^{\mathrm{TM}}$ untuk perhitungan pemecahan persoalan yang sudah teruji kehandalannya. Pemodelan AHP untuk pemilihan SMK TI dapat dilihat pada gambar 3 berikut ini:

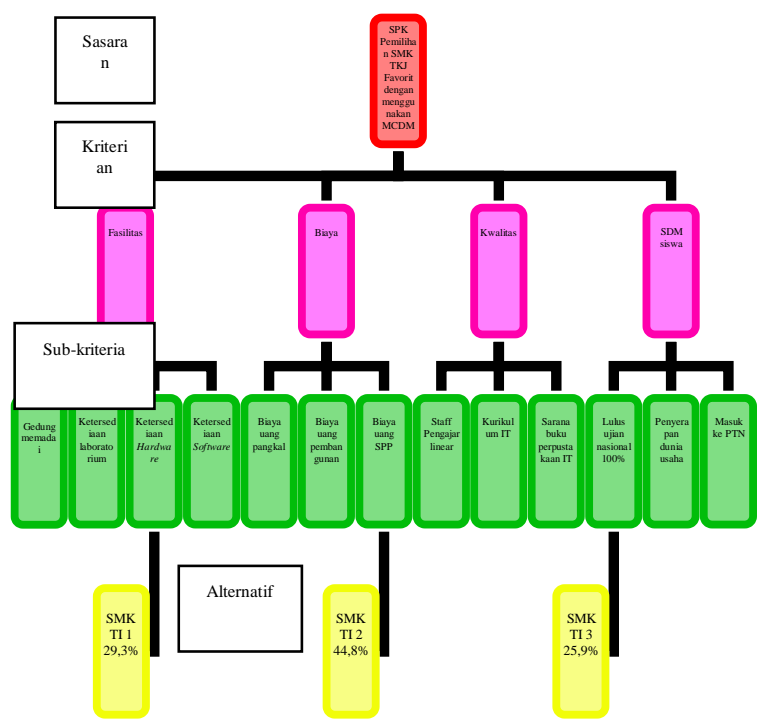

Gambar 3. Diagram Hirarki dan Keputusan dengan Pendekatan AHP

\section{HASIL DAN PEMBAHASAN}

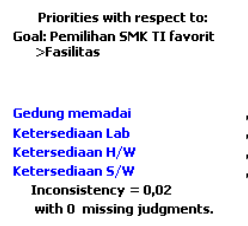

Gambar 4. Kriteria pemilihan fasilitas yang harus dipertimbangkan dalam pemilihan SMK TI beserta nilai bobotnya

Berdasarkan hasil pengolahan data responden ahli dalam gambar 4 diatas diperoleh bahwa prioritas utama atau tertinggi dalam kriteria fasilitas yaitu ketersediaan software dengan nilai bobot 0,338 atau sebanding dengan 33,8\% dari sisi fasilitas, urutan berikutnya ketersediaan hardware dengan nilai bobot 0,288 atau sebanding dengan 28,8\%, ketersediaan laboratorium dengan nilai bobot 0,205 atau sebanding dengan $20,5 \%$, dan peringkat prioritas kriteria yang terakhir adalah gedung memadai dengan nilai bobot 0,169 atau sebanding dengan $16,9 \%$.

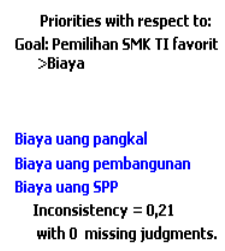

Biaya uang pangkal Biaya uang pembanguna Biaya uang SPP

Inconsistency $=0,21$

with 0 missing judgments.

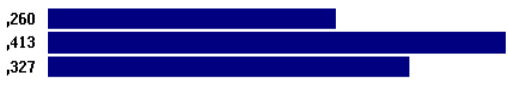

Gambar 5. Kriteria pemilihan biaya yang harus dipertimbangkan dalam pemilihan SMK TI beserta nilai bobotnya

Berdasarkan hasil pengolahan data responden ahli dalam gambar 5 diatas diperoleh bahwa prioritas utama atau tertinggi dalam kriteria biaya yaitu biaya uang pembangunan dengan nilai bobot 0,413 atau sebanding dengan $41,3 \%$, urutan berikutnya biaya uang SPP dengan nilai bobot 0,327 atau sebanding dengan $32,7 \%$ dan peringkat prioritas kriteria yang terakhir dari kriteria biaya adalah biaya uang pangkal dengan nilai bobot 0,260 atau sebanding dengan $26 \%$.
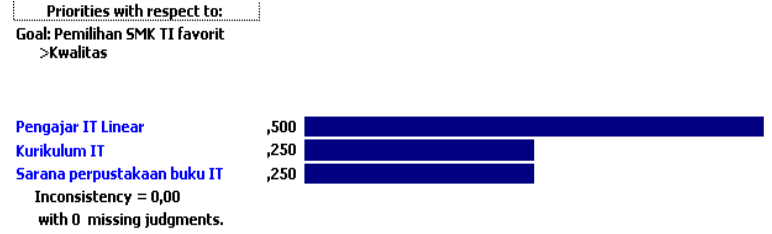

Gambar 6. Kriteria pemilihan kwalitas yang harus dipertimbangkan dalam pemilihan SMK TI beserta nilai bobotnya

Berdasarkan hasil pengolahan data responden ahli dalam gambar 6 diatas diperoleh bahwa prioritas 
utama atau tertinggi dalam kriteria kwalitas yaitu staff pengajar IT linear dengan nilai bobot 0,500 atau sebanding dengan $50 \%$, urutan berikutnya adalah kurikulum IT dan sarana perpustakaan buku IT dengan nilai bobot 0,250 atau sebanding dengan $25 \%$.

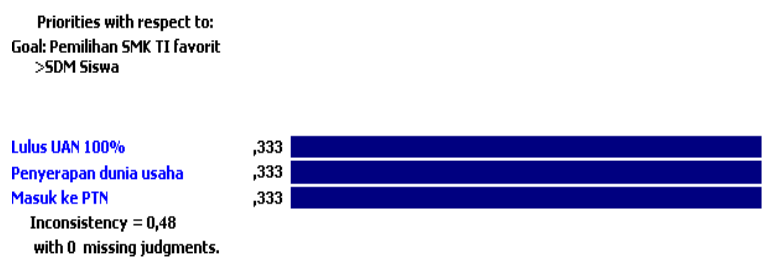

Gambar 7. Kriteria pemilihan SDM Siswa yang harus dipertimbangkan dalam pemilihan SMK TI beserta nilai bobotnya

Berdasarkan hasil pengolahan data responden ahli dalam gambar 7 diatas diperoleh bahwa semua prioritas kriteria SDM siswa adalah sebanding yaitu sub-kriteria lulus Ujian Akhir Nasional 100\% dengan nilai bobot 0,333 atau sebanding dengan $33,3 \%$, sub-kriteria penyerapan dunia usaha dengan nilai bobot 0,333 atau sebanding dengan $33,3 \%$ dan kriteria lulus masuk ke PTN dengan nilai bobot 0,333 atau sebanding dengan $33,3 \%$.

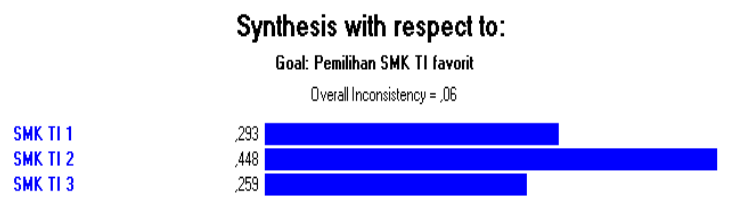

Gambar 8. Nilai Bobot Global Prioritas Alternatif Strategis Berdasarkan Penentuan Pemilihan SMK TI

Berdasarkan hasil pengolahan data responden ahli dalam gambar 8 diatas diperoleh bahwa prioritas utama atau tertinggi alternatif dalam strategis SPK pemilihan SMK TKJ favorit adalah SMK TI 2 dengan nilai bobot 0,448 atau sebanding dengan $44,8 \%$ dari total alternatif yang ditetapkan. Peringkat prioritas berikutnya adalah SMK TI 1 dengan nilai bobot 0,293 atau sebanding dengan 29,3\%. Peringkat prioritas kriteria yang terakhir adalah SMK TI 3 dengan nilai bobot 0,259 atau sebanding dengan $25,9 \%$ total alternatif yang ditetapkan.

\section{KESIMPULAN}

Setelah dilakukan pengolahan data menggunakan software Expert Choice 2000 maka diperoleh kesimpulan bahwa urutan prioritas dari paling tertinggi sampai yang terendah adalah

1. SMK TI 2 dengan nilai bobot $44,8 \%$.

2. SMK TI 1 dengan nilai bobot $29,3 \%$.

3. SMK TI 3 dengan nilai bobot $25,9 \%$. dari 3 buah kriteria pemilihan.

\section{DAFTAR PUSTAKA}

Chen, Zhifeng. 2005. Consensus in Group Decision Making Under Linguistic Assessments. A Dissertation, Department of Industrial and Manufacturing Systems Engineering College of Engineering Kansas State University, Manhattan Kansas.

Dedi Trisnawarman, Margaret Livereja, 2006. Jurnal: "Aplikasi Sistem Pengambilan Keputusan Pemilihan Sekolah".

Eddy Cahyadi, 2006, Kajian Business Continuity Plan Berdasarkan Kuantifikasi Nilai Ekonomis Sistem Aplikasi Pada Industri Penerbangan: Studi Kasus Pada PT. Garuda Indonesia. Tesis di Magister Teknologi Informasi Universitas Indonesia.

FAISAL, 2010. Strategi IT Rencana Penanggulangan Bencana (Disaster Recovery Planning/ DRP) Pada Core UICo System Dengan Pendekatan Analytical Hierarchy Process Studi Kasus UNOCAL Indonesia. Laporan karya ilmiah|Tugas Akhir|Tesis | Program Studi Ilmu Komputer Magister Ilmu Komputer, STMIK Nusa Mandiri Jakarta, 2010.

FAISAL, 2014. Penerapan metode AHP dalam Pemilihan Komputer dengan menggunakan Expert Choice. Laporan hibah penelitian dosen|Program Studi Sistem Informasi Universitas Bunda Mulia Jakarta, 2014.

FAISAL, 2015. Sistem Penunjang Keputusan Pemilihan Perangkat Lunak Pengolah Citra Dengan Metode Multi-Criteria Decision Making (MCDM) dan Analytical Hierarchy Process (AHP). Nasional|Prosiding Seminar Nasional Teknologi Informasi dan Multimedia (SEMNASTEKNOMEDIA 2015), ISSN: 2302-3805 STMIK AMIKOM Yogyakarta 6-8 Februari 2015.

FAISAL, 2015. Sistem Penunjang Keputusan Pemilihan Perangkat Pemrosesan Data Menggunakan Metode Analytical Hierarchy Process (AHP) Dan MultiCriteria Decision Making (MCDM). Seminar Nasional|Prosiding Konferensi Nasional Sistem Informasi (KNSI 2015), ISSN: 1907-9613 Universitas Klabat Menado Sulawesi Utara 26-28 Februari 2015.

Fitriyani, 2012. Jurnal: "Aplikasi AHP Sebagai Model SPK Pemilihan Tempat Kuliah di Bangka Belitung".

Fitriyani, 2012. Jurnal: "SPK Penjurusan SMA Mengunakan Metode AHP”.

JOGIYANTO 2008, Analisis dan Desain Sistem Informasi, Andi Offset, Yogyakarta. 
Marimin. 2004. Teknik dan Aplikasi Pengambilan Keputusan Kriteria Majemuk. Penerbit PT Grasindo, Jakarta.

Parmadiharto, 2007. Jurnal: "Rancang Bangun SPK Pemilihan SMA Swasta Favorit Degan Metode AHP Berbasis WEB".

Riki Khairul, 2012. Jurnal: "Perancangan SPK Penjurusan Dengan Menggunakan Metode AHP Pada SMAN 1 Ngaglik."

Roger, R. Flynn, \& Marek, J. Druzdzel. (2007). Decision Support Systems Encyclopedia of Library and Information Science, Second Edition (pp.794-802): Taylor \& Francis, Decision Systems Laboratory School of Information Sciences and Intelligent Systems Program University of Pittsburgh, Pittsburgh, PA 15260.

Saaty, R.W., The Analytic Hierarchy Process - What It Is and How It Used, Journal of Mathematical Modelling Vol. 9 no. 3-5, 1987.p. 161-176.

Saaty, T.L., 2004. Decision making - the analytic hierarichal process and the analytic network process. Journal of Systems Science and Systems Engineering. Vol 13(1) : 35.

Sri Andayani, (2012). Performance Assessment Dalam Perspektif Multiple Criteria Decision Making, Seminar Nasional Penelitian, Pendidikan dan Penerapan MIPA, Fakultas MIPA, Universitas Negeri Yogyakarta.

Suryadi, etc 2001, Sistem Pendukung Keputusan, Remaja Rosdakarya, Bandung.

Todhi Pristianto, 2010. Jurnal: "SPK Memilih Perguruan Tinggi Swasta Jurusan Komputer Menggunakan metode AHP”.

Turban, 2005, Decision Support Systems and Intelligent Systems (Sistem pendukung keputusan dan sistem cerdas) Jilid 1, Andi Offset, Yogyakarta. 